\title{
Historical perspectives of The American Association for Thoracic Surgery: Delos M. Cosgrove, MD (1940-)
}

\author{
James I. Fann, MD, ${ }^{\mathrm{a}}$ and Marc R. Moon, $\mathrm{MD}^{\mathrm{b}}$
}

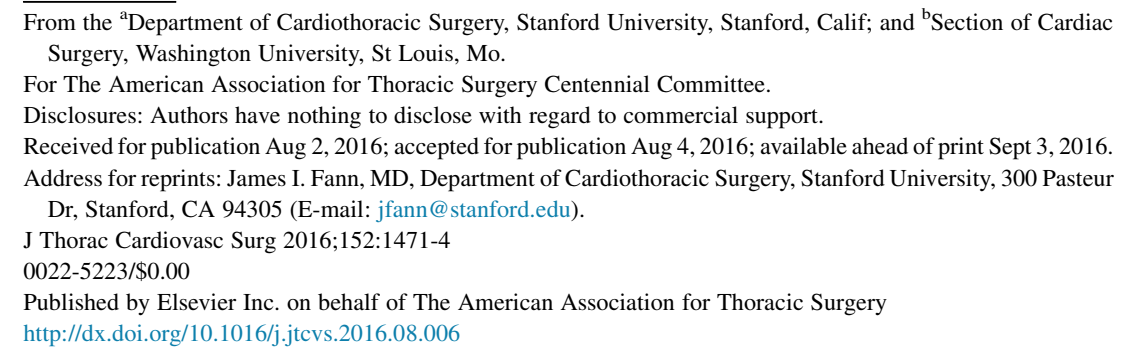

Delos M. "Toby" Cosgrove III, the 80th president of The American Association for Thoracic Surgery (AATS), was born in 1940 in Watertown, New York, to Delos Cosgrove, $\mathrm{Jr}$, and Margaret Norton ${ }^{1}$ (Figure 1). Both parents were educated in New England but returned to Watertown to raise a family. His father was a lawyer, as were his grandfather and great-grandfather. Cosgrove's parents were products of the Depression, and he was encouraged to pursue a profession that would enable him to make a significant contribution to society. Cosgrove was not unfamiliar with the medical profession because he had family friends who were physicians, but he was the first in his family to enter the medical field. Prophetically, at the age of 8 years, he decided to become a surgeon because of the profound influence of a family friend who was the chief of surgery at George Washington University. Cosgrove also quipped that he thought that he would "look good" wearing a surgical mask. ${ }^{1}$

Cosgrove was a good, but not stellar, student at Watertown High School, and he said that he often would take a long time to do his homework. ${ }^{1-3}$ In 1958, when he matriculated at Williams College, his father's alma mater, he had difficulties with his studies, particularly in the French language class. He graduated in 1962 and set his sights on a career in medicine. As will be noted later, it was not to be until his 30 s that Cosgrove was able to understand why he struggled in his academic endeavors. Confronting and overcoming challenges through sheer courage and determination would turn out to be a common theme throughout his career. After completing his undergraduate studies, the young Cosgrove attended the University of Virginia Medical School, a process that set in motion the maturation of an individual who was to have a major impact in medical innovation and the delivery of health care. ${ }^{2}$ During his medical school years, cardiac surgery was still relatively early in its development, and clinical successes in valve surgery and congenital procedures were exciting though highly unpredictable. At Virginia, Harry Muller, the Chief of Cardiac Surgery,

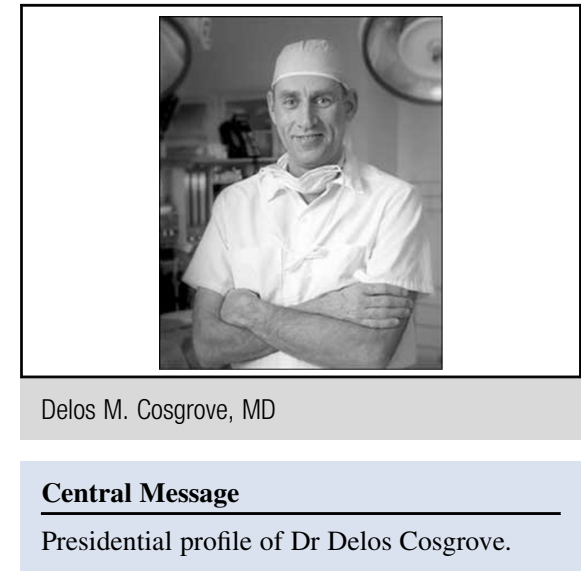

made a powerful imprint on Cosgrove, paving the path for his goal of becoming a cardiac surgeon. His passion for cardiac surgery was to carry him through the vicissitudes of his general surgery residency years, which was to be interrupted by the Vietnam War.

Throughout his many life experiences, Cosgrove recalled that he just had to "gut it out" and put in more work than most people. ${ }^{1,2}$ At medical school, he thrived in the clinical environment. In his senior year during a rotation at Boston Children's Hospital, Robert Gross (44th AATS president) took a particular interest in and mentored Cosgrove when he learned that Cosgrove had spent 2 summers in the early 1960s on the crew of the Nefertiti, a Boston-based yacht in the America's Cup races. ${ }^{1,3} \mathrm{~A}$ family friend who had invested in the building of the boat was able to get Cosgrove to try out for the crew. Because one member of the crew who stayed below deck got seasick, Cosgrove was able to join the crew as the "sewer man," which continues to this day as a position in America's Cup races. ${ }^{1,3}$

Cosgrove began his general surgical internship at the University of Rochester in $1966 .{ }^{1,4}$ After completing his internship and 1 year of residency, he entered the Air Force in the summer of 1968. Three weeks later, he was in Da Nang, Vietnam. Cosgrove's tour of duty further tested his mettle and resilience, as he served as the chief of the US Air Force Casualty Staging Flight in charge of the 100-bed facility, staffed by 2 doctors, 11 nurses, and numerous corpsman as medical assistants (Figure 2). During his tour, Cosgrove and his colleagues evacuated more than 22,000 sick and wounded soldiers, for which he was awarded the Bronze Star. He also received the Republic 


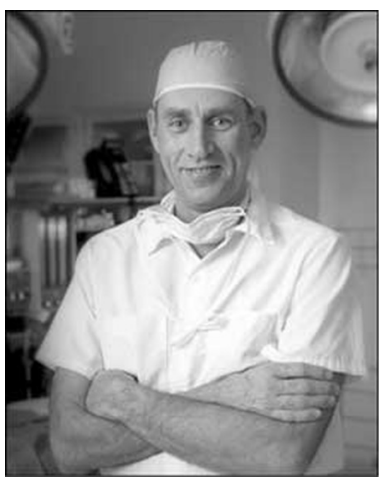

FIGURE 1. Photograph of Delos Cosgrove. (From http://dyslexia.yale. edu/cosgrove.html, accessed May 4, 2016.)

of Vietnam Commendation Medal for medical services that he volunteered to Vietnamese civilians. ${ }^{1,3}$

Returning from Vietnam with confidence in his surgical and organizational skills, Cosgrove continued surgical training at the Massachusetts General Hospital (MGH) program. ${ }^{1}$ During this period, he spent 1 year at the Brook Hospital in England rotating on the cardiac surgery service. After this invaluable surgical experience, he returned to MGH to complete his general surgery training. ${ }^{1,4}$ Remarkably, it was near the end of his general surgery residency that Cosgrove, at the age of 33 years, learned that he was dyslexic. ${ }^{1-3,5,6}$ As he struggled to pronounce some of the words in a newspaper article, the teacher that he was dating at the time put a name to the learning difficulties he had faced since he was a child. Whether Cosgrove felt relief on learning his diagnosis is not clear, but he remained steadfast in his goals. Cosgrove later credited the success of career to his dyslexia and continued to inspire those with dyslexia in his works and writings. He noted, "We're not very good at the scholastic stuff, but we see other things that are different. And that's a big advantage." $1,3,5$

After completing his general surgery residency in 1974, Cosgrove wanted to pursue further training in cardiac surgery and went to work with Aldo Castaneda (74th AATS president) as the chief resident at Boston Children's Hospital. Upon completing this fellowship, Cosgrove was without an offer of employment; undiscouraged, he spent the next 6 months collaborating with Sade and Castenada ${ }^{7}$ to author a book on the management of infants and children during cardiac surgery. ${ }^{1}$ A few months into the project, Cosgrove was contacted by Floyd Loop (78th AATS president), who, as the new head of cardiac surgery at the Cleveland Clinic, had the foresight to offer him a staff position. It was particularly fortuitous because this was the period when the Clinic was emerging as a prominent cardiovascular institution during the advent of coronary artery bypass surgery and valve surgery. ${ }^{1,8}$ Cosgrove was now in his element because there were 6 surgeons performing 3000 cardiac operations a year.

As the reputation of the Clinic grew under Loop's leadership, Cosgrove looked for opportunities to continue to create and innovate. He had earned international renown

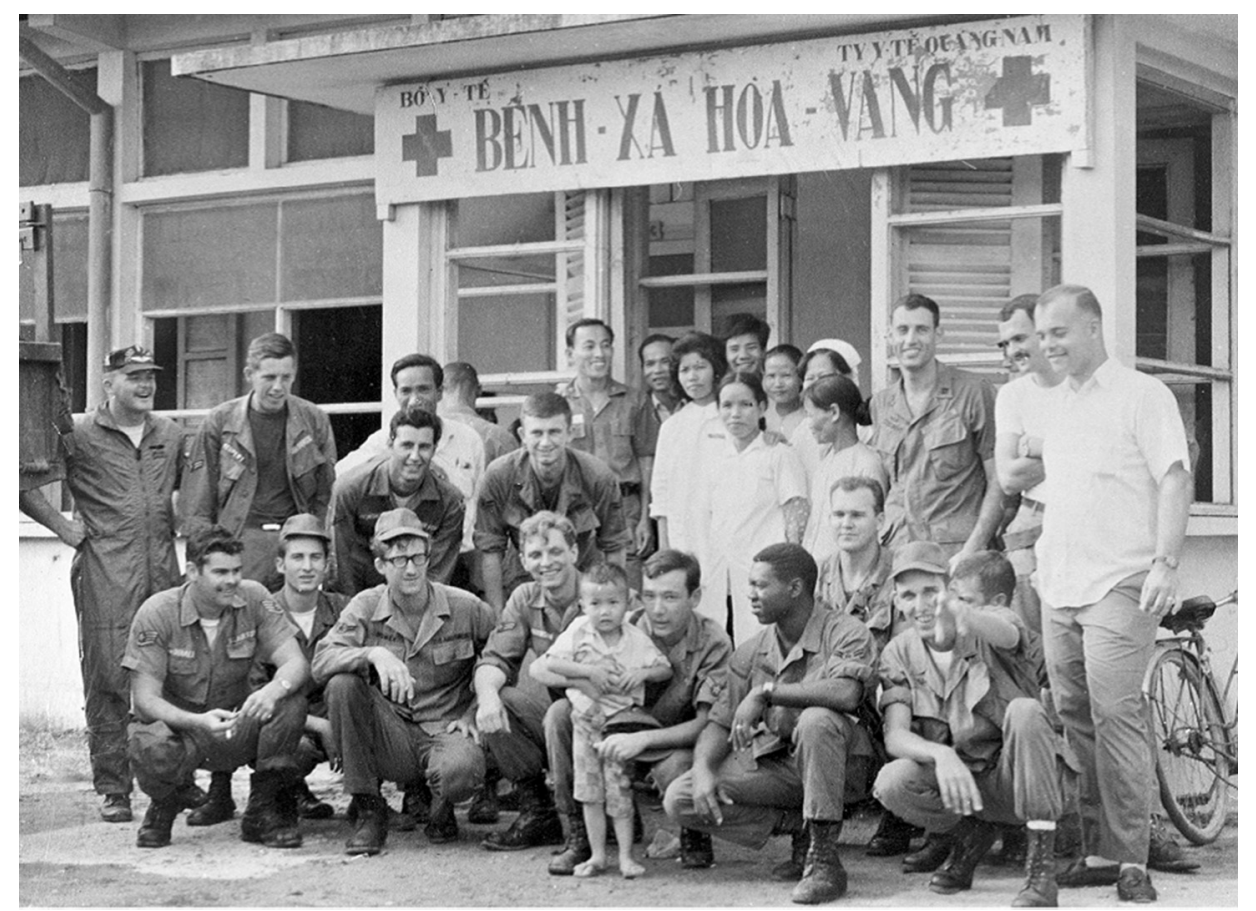

FIGURE 2. Delos Cosgrove (back row, third from right) and his surgical team in Vietnam. (Modified from http://aats.org/annualmeeting/Program-Books/ 2014/presentations/584/Toby.pdf, accessed May 4, 2016.) 
in cardiac surgery, particularly in valve surgery, and it was time to consider approaches other than the conventional open surgical one. In the mid 1990s, cardiac surgeons at many institutions were developing various minimally invasive techniques. At this time, Cosgrove conceptualized novel approaches and created instruments to perform less-invasive valve surgery. ${ }^{1}$ After experimenting in the laboratory and armed with clinical experience, Cosgrove with the assistance of his wife Anita, an award-winning media producer, conducted a live broadcast of a minimally invasive valve surgery to 30 locations across 5 continents.

In 2000, as the AATS president, Cosgrove discussed "the innovation imperative" and how surgeons have to "think anew and act anew" in clinical practice, education, research, and health care delivery. ${ }^{1,9} \mathrm{He}$ stressed that leaders in cardiothoracic surgery needed to innovate and change to survive and prosper. He made a compelling case for the universal expansion of residency training programs to 3 years with focused training in one of the cardiac subspecialties and pointed to the imperative to fund basic, translational, and clinical research through public and private sources. Further, he emphasized the need to center the debate about health care delivery on optimizing value by simultaneously maximizing quality and reducing cost. Guest speakers at the meeting included Craig Venter, one of the first to sequence the human genome, and Jim Barksdale of Netscape, which was one of the early Internet search engines. ${ }^{1}$ Cosgrove pointed out that to innovate and achieve something substantial, not only in cardiac surgery but also in many aspects of society, one has to be willing to accept risk and failure. ${ }^{1,9}$

In 1989, Loop became Chief Executive Officer of the Clinic, and Cosgrove was named chairman of the department of thoracic and cardiovascular surgery. After an illustrious career, Loop stepped down as Chief Executive Officer in 2004, and Cosgrove was chosen as his successor. ${ }^{1,8}$ In his position, Cosgrove presided over an $\$ 8$ billion health care system comprising the main Clinic, 9 regional hospitals, and 21 family health and ambulatory surgery centers. ${ }^{4}$ Initially, he focused on 2 major medical and by extension economic issues: smoking and obesity. ${ }^{10-13}$ Because Cosgrove's father died of emphysema from cigarette smoking, the economics of health care with respect to habits became personal. ${ }^{1}$ Believing that the Clinic could serve as a model for the community, he initiated an effort against smoking and a controversial campaign to stop hiring smokers. ${ }^{1,10-12}$ Cosgrove contended that the wellness philosophy that began at the Clinic could seed the community locally and then extend statewide and nationally. The decrease in smoking from $28 \%$ to $15 \%$ in Cuyahoga County was considered a direct result of the effort of the Clinic combined with the 2006 statewide ban on smoking at work and in public places. ${ }^{1}$ The second of the 2-prong effort, namely, how to decrease the incidence of obesity, proved to be more controversial. ${ }^{11}$ Nonetheless, Cosgrove confronted this issue by altering the habits of the Clinic employees. Healthy foods were served in the Clinic's cafeteria, and the employees were encouraged to exercise and were provided with free exercise programs. ${ }^{1,10-12}$ The digital health records of nearly all patients were synchronized with smart technology to permit patients to upload health information directly from home devices such as scales, blood-pressure monitors, and glucometers. Thus, patients were able to track their progress, and doctors could monitor the effectiveness of the treatments. Of note, Cosgrove emphasized patient care and experience and reorganized clinical services into patient-centered and organ and disease-based institutes. $\mathrm{He}$ enacted policies focused on quality improvement and greater transparency and accountability. Cosgrove also committed the Clinic to provide major support to local schools, hunger centers, and high school apprenticeship programs in health care.

Cosgrove always considered himself to be the beneficiary of great support from his wife and family. ${ }^{1}$ In the mid1970s, Cosgrove married Anita Desiderio, who was a nurse in the intensive care unit at MGH. She later earned a master's degree in communications and became an Emmy award-winning documentary writer producer. She continued her education, graduating with distinction from law school at Case Western Reserve University. In her many executive roles, Anita served as chief communications officer for a global telemedicine company, director of strategic alliances for a personal genomics company, and director of provider relations of a health care information company. She also served on the advisory board of Cleveland Clinic's Global Arts and Medicine Institute. The Cosgroves have 2 daughters.

During his academic career, Cosgrove published approximately 450 journal articles and book chapters. Along with co-authorship of Infant and Child Care in Heart Surgery. ${ }^{1,4}$ he developed 17 training and continuing medical education films. In 2013, he wrote The Cleveland Clinic Way, ${ }^{14}$ focused on the trends for the future of health care and the role of the Clinic in business strategy and quality. A member of 16 scientific societies, including the AATS, Society of Thoracic Surgeons, American College of Surgeons, and American Heart Association, Cosgrove served as an honorary member of 6 international organizations, including an Honorary Fellowship of the Royal College of Surgeons in Ireland. ${ }^{4,15}$ In 2013, he was elected to the Institute of Medicine. As an innovator with 30 patents in medical products, Cosgrove helped establish Cleveland Clinic Innovations, the technology transfer and commercialization arm that spun off 60 medical technology companies. He received the Cleveland Clinic's Master Clinician Award, the Innovator of the Year Award, and the 
Lerner Humanitarian Award. He served as a trustee of Williams College and as a member of Cleveland Medical Hall of Fame and Cleveland Business Hall of Fame. In 2007, he was named Cleveland Business Executive of the Year. He also received the Woodrow Wilson Center Award for Public Service and the Harvard Business School's Award from Alumni of the Harvard Business School. ${ }^{4,15}$

Cosgrove's philosophy of life can be summarized in the following. When Cosgrove was in high school, his father took him to see his old college professor Charles Keller, the chairman of the history department and director of admissions at Williams College. ${ }^{1,16}$ Cosgrove recalled, "He said to my father, 'Don't tell me Toby's grades or his IQ. Tell me his GQ.' We looked at each other-what on earth was he talking about? 'His GQ, his guts quotient, because that's much more important than his IQ.", 1,16 Cosgrove further noted, "You learn that over time it's not a sprint, it's a marathon, and it's a person's determination that keeps them going, even when things don't look particularly bright." ${ }^{1}$ In "the tests of life" or GQ, Cosgrove has few rivals.

\section{References}

1. Moon MR. AATS Interview: In the Words of Our Presidents: Delos M. Cosgrove: July 12, 2011. AATS Centennial, pending publication.

2. Shaywitz S. Overcoming Dyslexia. New York: Vintage Books, Random House; 2005.

3. Ditz L. High achieving dyslexics: Toby Cosgrove, June 27, 2004. Available at: http:// lizditz.typepad.com/i_speak_of_dreams/2004/06/high_achieving_html. Accessed May 3, 2016.
4. Cleveland Clinic Foundation. Delos Cosgrove, MD. Available at: http://my. clevelandclinic.org/staff_directory/staff_display?doctorid=237. Accessed May 4, 2016.

5. The Yale Center for Dyslexia \& Creativity. Delos "Toby" Crosgrove, M.D. Available at: http://dyslexia.yale.edu/cosgrove.html. Accessed August 20, 2015.

6. DyslexiaHelp: University of Michigan. Success story: Toby Cosgrove. Available at: http://dyslexiahelp.umich.edu/success-stories/toby-cosgrove. Accessed August 20, 2015.

7. Sade RM, Cosgrove DM, Castaneda AR. Infant and Child Care in Heart Surgery. Chicago: Year Book Medical Publishers; 1977.

8. Conte JV. Historical perspectives of The American Association for Thoracic Surgery: Floyd D. Loop (1936-2015). J Thorac Cardiovasc Surg. 2016;151:607-9.

9. Cosgrove DM. The innovation imperative. J Thorac Cardiovasc Surg. 2000;120: 839-42.

10. Park A. This doctor does not want to see you. Time Magazine. June 17, 2009. Available at: http://content.time.com/time/specials/packages/article/0,28804, 19038731903925 1903787,00.html. Accessed May 3, 2016.

11. Leohardt D. The way we live now: fat tax. New York Times Magazine. August 16, 2009. Available at: http://www.nytimes.com/2009/08/16/magazine/16FOBwwln-t.html?_r=0. Accessed May 3, 2016.

12. Colvin G. Cleveland Clinic chief on the business of health. Available at: http:// archive.fortune.com/2010/02/17/news/companies/cleveland_clinic_cosgrove. fortune/index.htm. Accessed May 3, 2016.

13. Interlandi J. Cleveland Clinic CEO speaks on health-care reform: "We May End Up Making the Problem Substantially Worse." Newsweek Magazine. August 7, 2009. Available at: http://www.newsweek.com/cleveland-clinic-ceo-speakshealth-care-reform-we-may-end-making-problem-substantially-worse-222200. Accessed May 3, 2016.

14. Cosgrove T. The Cleveland Clinic Way: Lessons in Excellence From One of the World's Leading Health Care Organizations. New York: McGraw-Hill Education; 2014.

15. World Congress. Speaker biography: Toby Cosgrove. Available at: https://www. worldcongress.com/speakerBio.cfm?speakerID=1368. Accessed May 4, 2016.

16. Cosgrove T. Best Advice: tell me your GQ (guts quotient), not your IQ. Available at: https://www.linkedin.com/pulse/best-advice-tell-me-your-gq-guts-quotientiq-toby-cosgrove. Accessed May 3, 2016. 